\title{
Thermodynamics and kinetics of sulfide oxidation by oxygen: a look at inorganically controlled reactions and biologically mediated processes in the environment
}

\author{
George W. Luther III ${ }^{1}$, Alyssa J. Findlay ${ }^{1}$, Daniel J. MacDonald ${ }^{1}$, Shannon M. Owings ${ }^{1}$, Thomas E. Hanson', \\ Roxanne A. Beinart ${ }^{2}$ and Peter R. Girguis ${ }^{2}$
}

School of Marine Science and Policy, College of Earth, Ocean and Environment, University of Delaware, Lewes, DE, USA

2 Department of Organismic and Evolutionary Biology, Harvard University, Cambridge, MA, USA

\section{Edited by:}

Martin G. Klotz, University of Louisville, USA

\section{Reviewed by:}

Marc Strous, Max Planck Institute for

Marine Microbiology, Germany

Donald A. Bryant, The Pennsylvania

State University, USA

*Correspondence:

George W. Luther III, School of Marine Science and Policy, College of Earth,

Ocean and Environment, University of Delaware, 700 Pilottown Road, Lewes, DE 19958, USA.

e-mail: luther@udel.edu
The thermodynamics for the first electron transfer step for sulfide and oxygen indicates that the reaction is unfavorable as unstable superoxide and bisulfide radical ions would need to be produced. However, a two-electron transfer is favorable as stable $\mathrm{S}(0)$ and peroxide would be formed, but the partially filled orbitals in oxygen that accept electrons prevent rapid kinetics. Abiotic sulfide oxidation kinetics improve when reduced iron and/or manganese are oxidized by oxygen to form oxidized metals which in turn oxidize sulfide. Biological sulfur oxidation relies on enzymes that have evolved to overcome these kinetic constraints to affect rapid sulfide oxidation. Here we review the available thermodynamic and kinetic data for $\mathrm{H}_{2} \mathrm{~S}$ and $\mathrm{HS} \cdot$ as well as $\mathrm{O}_{2}$, reactive oxygen species, nitrate, nitrite, and $\mathrm{NO}_{\times}$species. We also present new kinetic data for abiotic sulfide oxidation with oxygen in trace metal clean solutions that constrain abiotic rates of sulfide oxidation in metal free solution and agree with the kinetic and thermodynamic calculations. Moreover, we present experimental data that give insight on rates of chemolithotrophic and photolithotrophic sulfide oxidation in the environment. We demonstrate that both anaerobic photolithotrophic and aerobic chemolithotrophic sulfide oxidation rates are three or more orders of magnitude higher than abiotic rates suggesting that in most environments biotic sulfide oxidation rates will far exceed abiotic rates due to the thermodynamic and kinetic constraints discussed in the first section of the paper. Such data reshape our thinking about the biotic and abiotic contributions to sulfide oxidation in the environment.

Keywords: sulfide, oxidation, abiotic, biotic, Chlorobaculum tepidum, chemolithotrophy, photolithotrophy

\section{INTRODUCTION}

The oxidation of hydrogen sulfide is arguably one of the most important processes in the environment as the oceans have been suboxic or anoxic and euxinic (i.e., sulfidic) for long spans of geologic time (Canfield and Raiswell, 1999; Turchyn and Schrag, 2006).These are the oceans in which eukaryotes evolved and sulfur metabolism may have helped shape initial symbiotic events leading to the eukaryotic lineage (Overmann and van Gemerden, 2000; Theissen et al., 2003; Mentel and Martin, 2008). Modern analogs of these euxinic environments can be found in anoxic marine basins like the deep Black Sea (Wakeham et al., 2007), near the Cariaco Trench (Lin et al., 2008), and highly sulfidic marine sediments like those in the Santa Barbara Basin that have been characterized as symbiosis oases (Bernhard et al., 2000). Other oceanic regions experience periodic anoxia and sulfidic water columns due to the disturbance of sulfide laden sediments underlying areas of high primary productivity, like the upwelling zones off the coasts of Chile (Canfield et al., 2010) and Namibia (Bruchert et al., 2003). In addition, hydrothermal vents are a key source of $\mathrm{H}_{2} \mathrm{~S}$ to the ocean and for vent associated ecosystems supported by sulfide driven chemolithotrophic primary production (Jannasch and Wirsen, 1979).
The sulfide produced in modern systems is released to overlying waters where it can be a toxin for aerobic organisms (Eghbal et al., 2004; Julian et al., 2005). At many sites where sulfide emanates, various microbes form microbial mats (Jorgensen, 1994; Baumgartner et al., 2006), and these organisms as well as macrofauna carrying microbial have the capability of oxidizing sulfide using chemical oxidants such as $\mathrm{O}_{2}$ and $\mathrm{NO}_{3}^{-}$(Jorgensen and Gallardo, 1999; Girguis et al., 2000) while using the energy released to survive and grow. In the deep sea sulfide oxidation using oxygen as oxidant forms the basis for symbiotic associations, most notably the association between the Vestimentiferan tubeworm Riftia pachyptila with its sulfide-oxidizing gamma proteobacterial community found in the trophosome, a specialized organ (Wilmot and Vetter, 1990; Arndt et al., 2001). In shallower environments, phototrophic anaerobic microbes use sunlight to affect the oxidation of sulfide via the enzyme systems sulfide:quinone oxidoreductase (SQR; e.g., Theissen et al., 2003) or flavocytochrome $c$ (FCC, also known as flavocytochrome $c$ sulfide dehydrogenase; Reinartz et al., 1998).

In addition to biologically mediated sulfide oxidation, oxidized metal compounds such as $\mathrm{Fe}(\mathrm{III})$ and $\mathrm{Mn}$ (III, IV) phases are efficient chemical oxidants for sulfide (Poulton et al., 2004; Yücel et al., 2010). In sediments and at the interface zones of sulfide and 
oxygen in anoxic basins, dissolved $\mathrm{Mn}$ and Fe are present and help to overcome the kinetic barrier to sulfide oxidation with oxygen as $\mathrm{Mn}$ (II) and $\mathrm{Fe}$ (II) can be oxidized abiotically or by microbial activity (Trouwborst et al., 2006; Clement et al., 2009). Here the oxidation of $\mathrm{Fe}$ (II) and $\mathrm{Mn}$ (II) to $\mathrm{Fe}$ (III) and $\mathrm{Mn}$ (III, IV) chemical species permit the oxidation of sulfide, which is a trace metal catalyzed process as $\mathrm{Fe}$ (II) and $\mathrm{Mn}$ (II) are regenerated (Konovalov et al., 2003; Ma et al., 2006; Yakushev et al., 2009).

While the importance of microbial biochemistry to sulfide oxidation in many systems is recognized (e.g., Lavik et al., 2009), this paper seeks to provide a concise demonstration of the underlying chemical principles for this observation. In this paper, we summarize the thermodynamics of one and two-electron transfers in sulfide oxidation showing that one-electron transfers are unfavorable whereas two-electron transfers are favorable. However, twoelectron transfers have a kinetic barrier for the direct reaction of sulfide and oxygen, which is a paramagnetic species, or of sulfide with nitrate. To demonstrate this point clearly, we compare abiotic rates of sulfide oxidation with $\mathrm{O}_{2}$ under trace metal clean conditions as well as with biotic rates for the anaerobic photolithotroph, Chlorobaculum tepidum, and aerobic chemolithotrophic bacterial symbionts from Lau Basin and free-living microbial communities from the Juan de Fuca Ridge. These data reveal that microbes enhance sulfide oxidation by three or more orders of magnitude and indicate that chemolithotrophic organisms are able to overcome the kinetic barrier for the reaction of sulfide with oxygen. By comparison with existing literature data, we demonstrate that biological sulfide oxidation rates will exceed trace metal catalyzed abiotic sulfide oxidation rates under many conditions.

\section{MATERIALS AND METHODS ABIOTIC REACTIONS}

All abiotic sulfide oxidation experiments were performed in a class 100 clean bench to prevent metal contamination. Plastic falcon tubes and other materials were cleaned of trace metal contamination by performing the following procedure. First the plastic materials are cleaned with a detergent in deionized (DI) water; then for a day each in three consecutive acid baths of (1) 10\% trace metal clean $\mathrm{HCl}$ acid followed by DI water rinsing; (2) another $10 \%$ trace metal clean $\mathrm{HCl}$ acid followed by DI water rinsing; (3) 1\% ultra pure $\mathrm{HCl}$ acid followed by DI water rinsing. After the last step, the plasticware is used for reaction or stored in plastic freezer bags until needed. Pipette tips were left to soak in $10 \%$ trace metal clean $\mathrm{HCl}$ until needed and were rinsed with DI water before they were used.

The sulfide reactions with oxygen were performed in trace metal clean base, $\sim 15 \mathrm{mM} \mathrm{NaOH}$. The trace metal clean base was prepared by adding $\mathrm{NaOH}$ to air saturated DI water and then $0.01 \mathrm{M}$ $\mathrm{MgCl}_{2} \cdot 6 \mathrm{H}_{2} \mathrm{O}$ was added to precipitate any oxidized Fe and other trace metal contaminants. The solution is then centrifuged and decanted into an acid washed bottle. The $\mathrm{pH}$ of the resulting solution is about 12. A stock solution of sulfide was made by dissolving solid $\mathrm{Na}_{2} \mathrm{~S} \cdot 9 \mathrm{H}_{2} \mathrm{O}$ in trace metal clean base to give a concentration of $24 \mathrm{mg} \mathrm{mL}^{-1}(0.01 \mathrm{M})$. The solid $\mathrm{Na}_{2} \mathrm{~S} \cdot 9 \mathrm{H}_{2} \mathrm{O}$ was first rinsed with DI water and dried with a kimwipe before it was weighed and dissolved. An aliquot of a $\mathrm{Na}_{2} \mathrm{~S} \cdot 9 \mathrm{H}_{2} \mathrm{O}$ solution is then added to the oxygen saturated $(\sim 250 \mu \mathrm{M})$ base solution so that the total sulfide in the solution is 50 or $100 \mu \mathrm{M}$. The loss of $\mathrm{HS}^{-}$is monitored over time by UV-Vis spectrophotometry using the 230 -nm peak (Ellis and Golding, 1959). When an aliquot is taken for analysis, it is discarded and not returned to the reaction vessel. The vessel is shaken to insure air saturation after each aliquot is removed.

\section{BIOTIC REACTIONS}

Chlorobaculum tepidum is a phototrophic, anoxygenic sulfideoxidizing bacterium. Electrochemical methods were employed in order to measure the rate of sulfide loss in the presence of these bacteria under different light intensities.

\section{Culture growth}

Wild type C. tepidum (strain TLS 1, Wahlund et al., 1991) were grown at $42^{\circ} \mathrm{C}$ under $20 \mu \mathrm{mol}$ photons $\mathrm{m}^{-2} \mathrm{~s}^{-1}$ provided by a full spectrum $60 \mathrm{~W}$ incandescent bulb for 3 days in Pf-7 medium containing $2.71 \mathrm{mM}$ sulfide. Cultures were started by transferring $1 \mathrm{~mL}$ of a previously grown culture into a $100-\mathrm{mL}$ septum vial containing anoxic media, which was then pressurized with argon gas to 10 psi. The vial was stored in the dark for $45 \mathrm{~min}$, then transferred to a water bath for growth under the conditions specified above. After 3 days, $50 \mathrm{~mL}$ of cells were centrifuged at $3000 \mathrm{rpm}$ for $45 \mathrm{~min}$ and rinsed in anoxic HEPES buffer $(0.1 \mathrm{M}$, $\mathrm{pH} 7.4$ ) to remove salts from the cells. After three rinses, the cells were stored in $5 \mathrm{~mL}$ anoxic HEPES buffer in a sealed $20 \mathrm{~mL}$ septum vial. Conditions were kept anoxic by using a glove bag purged with ultra high purity argon gas for transferring the cells. To determine the number of cells in the culture, $90 \mu \mathrm{L}$ of cells were fixed with $10 \mu \mathrm{L}$ of paraformaldehyde and diluted 1000 -fold in $9 \mathrm{~mL}$ HEPES and $1 \mathrm{~mL}$ Triton X-100. Five milliliter of this solution were filtered through a $0.20-\mu \mathrm{m}$ polycarbonate filter, and biomass was found through direct counts done by fluorescence microscopy using 4',6-diamidino-2-phenylindole (DAPI) stain and a UV light (Cottrell and Kirchman, 2003). Concentrations were calculated from the average of 10 fields of view with a 250-s exposure time. The concentration of cells after the final rinse was $3.3 \times 10^{9}$ cells $\mathrm{mL}^{-1} \pm 0.4 \times 10^{9}$ cells $\mathrm{mL}^{-1}$.

\section{ANALYTICAL METHODS}

Voltammetry with solid state electrodes was used to monitor sulfide loss, and the details of the method are described in Brendel and Luther (1995) and Luther et al. (2008). Briefly, a typical threeelectrode cell for the placement of electrodes with ports for stirring, the introduction of materials, and the purging with argon was used to measure sulfide loss in situ and in the absence of oxygen. The cell consists of a $100-\mu \mathrm{m}$ gold amalgam $(\mathrm{Au}-\mathrm{Hg})$ working electrode, a platinum counter electrode, and a $\mathrm{Ag} / \mathrm{AgCl}$ reference electrode, used in conjunction with a DLK-60 electrochemical analyzer [Analytical Instrument Systems (AIS), Inc.]. AIS software was used to run the equipment, and data were analyzed using a program written in Python. Peak heights were converted to concentrations using the method of standard additions in HEPES buffer with no cells. Cyclic voltammetric scans were run from -0.1 to $-1.8 \mathrm{~V}$ and back to $-0.1 \mathrm{~V}$ at a scan rate of $2 \mathrm{~V} \mathrm{~s}^{-1}$. Two conditioning steps preceded each scan: one at $-0.9 \mathrm{~V}$ for $5 \mathrm{~s}$, which served as an electrochemical cleaning step to prevent sulfide from plating onto the electrode, and another at $-0.1 \mathrm{~V}$ for $2 \mathrm{~s}$ (Eq. 1). Under these experimental conditions, sulfide reacts at the $\mathrm{Au}-\mathrm{Hg}$ 
electrode to form a HgS surface via the following equations and the peak for the removal of sulfide from the $\mathrm{HgS}$ surface near $-0.7 \mathrm{~V}$ from Eq. 2 is used for analysis:

$\mathrm{HS}^{-}+\mathrm{Hg} \rightarrow \mathrm{HgS}+2 \mathrm{e}^{-}$

$\mathrm{HgS}+\mathrm{H}^{+}+2 \mathrm{e}^{-} \rightarrow \mathrm{HS}^{-}+\mathrm{Hg}$

The solution was stirred with a mechanical stirrer prior to each scan. The detection limit for sulfide using this method is about $0.2 \mu \mathrm{M}$.

Stock solutions of HEPES and sulfide were made from salts dissolved in DI water that was purged in a pressure equalizing dropping funnel for $45 \mathrm{~min}$ with ultra high purity argon gas prior to use. The sulfide solution was prepared as above by first rinsing the solid $\mathrm{Na}_{2} \mathrm{~S} \cdot 9 \mathrm{H}_{2} \mathrm{O}$ with DI water and drying it with kimwipes before being weighed and dissolved in degassed DI water.

\section{EXPERIMENTAL PROCEDURE FOR PHOTOTROPHIC SULFIDE OXIDATION}

Experiments were run in sterile, anoxic HEPES buffer $(0.1 \mathrm{M}, \mathrm{pH}$ 7.4) at $44^{\circ} \mathrm{C}$. Temperature was held constant using a water jacketed electrochemical cell mated to a thermostatically controlled water bath, and an argon purge was used to keep oxygen from entering the cell. Once anoxic conditions were established, an appropriate volume of cells was added to the cell and were diluted to the desired concentration. The number of cells used varied between experiments, and ranged from $3.0 \times 10^{8}$ to $1.4 \times 10^{10}$. Replicate experiments were conducted with different cultures to determine sulfide oxidation rate reproducibility. After a short period was allowed for the cells and solution to reach thermal equilibrium, up to $100 \mu \mathrm{M}$ sulfide was added. The electrochemical cell was then capped to eliminate headspace and minimize volatile sulfide loss. Electrochemical measurements were taken every $9 \mathrm{~s}$ throughout the course of the experiment. Light was provided by a full spectrum $60 \mathrm{~W}$ incandescent bulb and the intensity was measured using a LI-COR Biosciences LI-1400 data logger light meter inside the electrochemical cell and ambient light was measured to be $5 \mu \mathrm{mol}$ photons $\mathrm{m}^{-2} \mathrm{~s}^{-1}$. For dark conditions $\left(0 \mu \mathrm{mol}\right.$ photons $\left.\mathrm{m}^{-2} \mathrm{~s}^{-1}\right)$ the electrochemical cell was covered, and measurements with the light meter ensured that no light was infiltrating the cell. For each set of conditions, experiments were also run without cells in order to establish sulfide loss due to abiotic factors with voltammetric measurements taken every $30 \mathrm{~s}$ for an hour. Rates were calculated from the linear range of a plot of sulfide concentration $(\mu \mathrm{M})$ versus time for each experiment.

\section{DETERMINING RATES OF CHEMOLITHOTROPHIC SULFIDE OXIDATION BY SYMBIONTS}

All experiments were conducted on board the R/V Thomas G. Thompson during an expedition in June and July 2009 at Lau Basin. Ifremeria nautilei (Bouchet and Warén, 1991; Windoffer and Giere, 1997) snails were collected by the ROV JASON from the ABE vent field $\left(2045.794323^{\circ} \mathrm{S}, 17611.466148^{\circ} \mathrm{W}\right)$ during dive J2-423 from a depth of $2152 \mathrm{~m}$. Snails were brought to the surface in a thermally insulated container (Mickel and Childress, 1982). After arrival on board ship, the snails most responsive to touch were immediately placed into titanium flow-through, high-pressure respirometer aquaria (as in Henry et al., 2008), where they were maintained in 0.2 micron filter-sterilized flowing seawater for approximately $24 \mathrm{~h}$ at $15^{\circ} \mathrm{C}$ and $27.5 \mathrm{Mpa}$ prior to experimentation.
To simulate the seawater chemistry found in situ, the 0.2-micron filter-sterilized seawater was pumped into an acrylic gas equilibration column and bubbled with carbon dioxide, hydrogen sulfide, oxygen, and nitrogen to achieve the desired dissolved gas concentrations (Girguis and Childress, 2006). Seawater from the equilibration column was delivered to the three aquaria by high-pressure pumps (American Lewa, Inc. Holliston, MA, USA). High-pressure aquaria were maintained in our climate-controlled laboratory, while aquaria pressures were maintained at $27.5 \mathrm{Mpa}$ via diaphragm back pressure valves (StraVal, Inc.). Vessel effluents were directed through a computer-controlled stream-selection valve that diverted one stream to the analytical instrumentation every $30 \mathrm{~min}$ so that either the initial water or a chamber with live animals could be analyzed for chemical components. The analytical system consisted of a membrane-inlet quadrupole mass spectrometer to determine all dissolved gas concentrations, an inline oxygen optode (Golden Scientific Inc.), and an inline $\mathrm{pH}$ electrode (Radiometer Inc.). In addition to the mass spectrometric analyses, hydrogen sulfide concentrations were determined by a quantitative colorimetric assay (Cline, 1969). For this study, a voltammetric flow cell was also added to the inline analytical instrumentation (Luther et al., 2002) so that hydrogen sulfide, polysulfides, thiosulfate, and oxygen could be determined. All carbon dioxide and hydrogen sulfide measurements were confirmed and calibrated using discrete samples analyzed back using a Hewlett-Packard 5890 Series II gas chromatograph (as in Childress et al., 1991).

For these experiments, I. nautilei were placed in the respirometer aquaria and were maintained in conditions typical of those in situ, namely total dissolved inorganic carbon (i.e., $\Sigma \mathrm{CO}_{2}$ ) $=5.5$ to $6 \mathrm{mM}$, total dissolved sulfide (i.e., $\Sigma \mathrm{H}_{2} \mathrm{~S}$ ) from 312 to $650 \mu \mathrm{M}$, dissolved $\mathrm{O}_{2}$ from 110 to $180 \mu \mathrm{M}$, and dissolved $\mathrm{NO}_{3}=40-50 \mu \mathrm{M}$, $\mathrm{pH}=6.1$ to 6.6 , temperature $=15-30^{\circ} \mathrm{C}$, pressure $=27.5 \mathrm{Mpa}$,

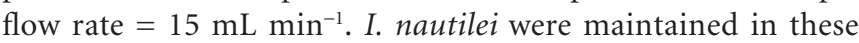
conditions until "autotrophy," during which they exhibited a net uptake of dissolved inorganic carbon, oxygen, and sulfide, as well as net elimination of proton equivalents. All dissolved substrate concentrations, as well as $\mathrm{pH}$ and temperature, were held at these "typical" conditions for the duration of the experiment. At the end of each experiment, snails were promptly removed, weighed on a motion-compensated shipboard balance, dissected, and frozen in liquid nitrogen for other analyses. Once removed, "free-living" microbes remained in the chambers and the aquaria were re-pressurized so experiments with only microbes could be performed.

\section{DETERMINING RATES OF CHEMOLITHOTROPHIC SULFIDE OXIDATION BY FREE-LIVING ASSEMBLAGES}

All experiments were conducted on board the $R / V$ Atlantis during an expedition in August 2008 to the Juan de Fuca ridge. Active solid sulfide samples were collected by the DSV Alvin using a sampling scoop, and were brought to the surface in a thermally insulated container (Mickel and Childress, 1982). After arrival on board ship, sulfide samples were immediately placed into titanium flowthrough, high-pressure respirometer aquaria (as in Henry et al., 2008), where they were maintained in $0.2 \mu \mathrm{m}$ filter-sterilized flowing seawater for approximately $24 \mathrm{~h}$ at $15^{\circ} \mathrm{C}$ and $27.5 \mathrm{Mpa}$ prior to experimentation. 
In situ seawater chemistry was simulated as described above. We incubated the sulfide samples at the following conditions: $5 \mathrm{mM}$ inorganic carbon, $650 \mu \mathrm{M}$ hydrogen sulfide, $110 \mu \mathrm{M}$ oxygen, $\mathrm{pH}$ 5.0 , temperature of $30^{\circ} \mathrm{C}$, and pressure of $27.5 \mathrm{Mpa}$ (ca. $4000 \mathrm{psi}$ ). All fluids were directed through a computer-controlled streamselection valve that diverted one stream to the analytical instrumentation every $30 \mathrm{~min}$ as described above. All dissolved substrate concentrations, as well as $\mathrm{pH}$ and temperature, were held at the aforementioned conditions for the duration of the experiment. At the end of each experiment, sulfide samples were promptly removed, weighed on a motion-compensated shipboard balance, dissected, and frozen in liquid nitrogen for other analyses.

\section{RESULTS AND DISCUSSION THERMODYNAMICS OF SULFIDE OXIDATION}

The thermodynamic equations and calculations for the reactions of sulfide with various oxidants have been demonstrated in Luther (2010), who used the thermodynamic data (at $25^{\circ} \mathrm{C}$ and $1 \mathrm{~atm}$ ) tabulated by Maloy (1985), Stumm and Morgan (1996) and Stanbury (1989). Briefly a reduction half reaction and an oxidation half reaction are combined to provide a $\Delta \mathrm{G}$ or $\Delta \log \mathrm{K}$, which indicates the favorability of a given reaction over $\mathrm{pH}$. For example the one-electron transfer reaction (Eq. 3) of $\mathrm{O}_{2}$ with $\mathrm{HS}^{-}$leads to two thermodynamically unfavorable products (superoxide ion and bisulfide radical).

$\mathrm{O}_{2(\mathrm{aq})}+\mathrm{HS}^{-} \rightarrow \mathrm{O}_{2(\mathrm{aq})}^{-}+\mathrm{HS} \bullet$

The thermodynamic functions for the reduction half reactions are Eqs 4 and 5. The function peis the $\log \mathrm{K}$ for the half reaction at a given $\mathrm{pH} ; \mathrm{p}^{\circ}$ is the $\log \mathrm{K}$ value at the standard state for all reactants and products. The complete reaction for Eq. 3 is the sum of Eq. 4 minus Eq. 5. An extensive list of half reactions are given in Luther (2010).

$\mathrm{O}_{2(\mathrm{aq})}+\mathrm{e}^{-} \rightarrow \mathrm{O}_{2(\mathrm{aq})}^{-} \quad \mathrm{p} \varepsilon=\mathrm{p}^{\circ}=-2.72$

$\mathrm{HS} \bullet+\mathrm{H}^{+}+\mathrm{e}^{-} \rightarrow \mathrm{H}_{2} \mathrm{~S} \quad \mathrm{p} \varepsilon=\mathrm{p}^{\circ}-\mathrm{pH}=25.21-\mathrm{pH}$

Similarly, the two-electron transfer reaction of $\mathrm{O}_{2}$ with $\mathrm{H}_{2} \mathrm{~S}$ leads to stable products (Eq. 6).

$\mathrm{O}_{2(\mathrm{aq})}+\mathrm{H}_{2} \mathrm{~S} \rightarrow \mathrm{S}^{0}+\mathrm{H}_{2} \mathrm{O}_{2}$

The thermodynamic functions for the reduction half reactions describing Eq. 6 are given in Eqs 7 and 8. Equation 6 is an accurate representation for the energy driving chemolithotrophy by an aerobic sulfide oxidizer using $\mathrm{O}_{2}$ as the terminal electron acceptor.

$$
\begin{aligned}
& 1 / 2 \mathrm{O}_{2(\mathrm{aq})}+\mathrm{H}^{+}+\mathrm{e}^{-} \rightarrow 1 / 2 \mathrm{H}_{2} \mathrm{O}_{2} \mathrm{p} \varepsilon=\mathrm{p}^{\mathrm{o}}-\mathrm{pH}=13.18-\mathrm{pH} \\
& 1 / 2 \mathrm{~S}+\mathrm{H}^{+}+\mathrm{e}^{-} \rightarrow 1 / 2 \mathrm{H}_{2} \mathrm{~S} \mathrm{p} \varepsilon=\mathrm{p} \varepsilon^{\mathrm{o}}-\mathrm{pH}=2.44-\mathrm{pH}
\end{aligned}
$$

Figure 1 shows plots over $\mathrm{pH}$ for one and two-electron transfer reactions for the reaction of sulfide with oxygen, reactive oxygen species and oxidized nitrogen species. In some instances there is no $\mathrm{pH}$ dependence for a given reaction, but in most instances there is a significant $\mathrm{pH}$ dependence. Figure 1A describes the thermodynamics of sulfide oxidation in one-electron transfers of oxygen in four steps from $\mathrm{O}_{2}$ to $\mathrm{O}_{2}^{-}$to $\mathrm{H}_{2} \mathrm{O}_{2}$ to $\mathrm{OH} \bullet$ to produce $\mathrm{H}_{2} \mathrm{O}$. Only $\mathrm{OH} \bullet$ can lead to formation of HS. Even the oxidation of sulfide by $\mathrm{O}_{3}$ and ${ }^{1} \mathrm{O}_{2}$ are unfavorable. However, the two-electron transfer reactions (e.g., Eq. 6) for $\mathrm{O}_{2}$ to $\mathrm{H}_{2} \mathrm{O}_{2}, \mathrm{H}_{2} \mathrm{O}_{2}$ to $\mathrm{H}_{2} \mathrm{O},{ }^{1} \mathrm{O}_{2}$ to $\mathrm{H}_{2} \mathrm{O}_{2}$, and $\mathrm{O}_{3}$ to $\mathrm{O}_{2}$ and $\mathrm{H}_{2} \mathrm{O}$ are thermodynamically favorable over all $\mathrm{pH}$.

Figures 1C,D are the data for the one-electron and two-electron transfer reactions of oxidized nitrogen species with sulfide. Again one-electron transfer reactions are not thermodynamically favorable over all $\mathrm{pH}$ as HS• results whereas two-electron transfer reactions are favorable. The one-electron thermodynamic calculations show that the oxidation of sulfide by other oxidants has similar problems as $\mathrm{O}_{2}$. Also, the reaction of sulfide at near neutral or basic $\mathrm{pH}$ has a kinetic constraint as nitrate and nitrite are anions as is $\mathrm{HS}^{-}$; thus, two negative species repel each other as they come near each other in the transition state.

A major problem for the reaction of $\mathrm{O}_{2}$ with any reactant that can donate a pair of electrons is the partial occupancy of the highest occupied $\pi$ antibonding orbitals, which are similar in energy (Figure 2). A direct two-electron transfer is not possible and a oneelectron transfer requires the unpairing of electrons in a donor such as sulfide. Thus, there is a kinetic constraint on $\mathrm{O}_{2}$ reactivity and this constraint needs to be overcome as it is in chemolithotrophic sulfide-oxidizing microbes. On the other hand, these kinetic constraints allow sulfide to persist for long enough periods in oxic and nitrate dominated environments thereby defining niches that can be exploited by sulfide-oxidizing microbes.

Figure 3 shows the $\Delta \mathrm{G}$ for three reaction sequences. First, the oneelectron transfer sequential reactions of $\mathrm{O}_{2}$ with $\mathrm{H}_{2} \mathrm{~S}$ to form $\mathrm{O}_{2}^{-}$and $\mathrm{HS} \bullet$ and of $\mathrm{O}_{2}^{-}$with $\mathrm{HS} \bullet$ to form $\mathrm{H}_{2} \mathrm{O}_{2}$ and $\mathrm{S}(0)$ (blue). In this case, the first step is thermodynamically unfavorable. A second reaction possibility is the reaction of $\mathrm{O}_{2}$ with $\mathrm{H}_{2} \mathrm{~S}$ to form $\mathrm{O}_{2}^{-}$and $\mathrm{HS} \bullet$ followed by the reaction of another $\mathrm{O}_{2}$ with $\mathrm{HS} \bullet$ to form $\mathrm{O}_{2}^{-}$and $\mathrm{S}(0)$. Again, the first step is thermodynamically unfavorable. The direct two-electron transfer reaction of $\mathrm{O}_{2}$ with $\mathrm{H}_{2} \mathrm{~S}$ described in Eq. 6 (red) is favorable.

\section{ABIOTIC REACTION OF SULFIDE WITH OXYGEN}

A concrete demonstration of kinetic limitations on the direct oxidation of sulfide by $\mathrm{O}_{2}$ can be found by examining the reaction of bisulfide ion $\left(\mathrm{HS}^{-}\right.$) with excess $\mathrm{O}_{2}$ in basic solutions. Over the $\mathrm{pH}$ range 8-12, Millero et al. (1987) showed that the kinetics of oxidation do not change at constant temperature $(\mathrm{T})$ and ionic strength (I) where $\mathrm{HS}^{-}$is the dominant sulfide species. Figure 4 shows a plot for the abiotic oxidation of sulfide in air saturated solutions at a $\mathrm{pH}$ of 12 and $25^{\circ} \mathrm{C}$ using trace metal clean base solution. The slope of the $\ln$ (sulfide) versus time shows pseudo first order behavior and yields the pseudo first order rate constant, $k$. For three replicates, $k$ is $7.12 \times 10^{-3}$ day $^{-1}\left( \pm 1.96 \times 10^{-4}\right)$. The half-life is $55 \pm 1$ day and the loss of sulfide is $0.91 \mu \mathrm{M}$ day ${ }^{-1}$.

We compare our data with those of Millero et al. (1987). In their work, they found the rate expression

$-d\left[\mathrm{H}_{2} \mathrm{~S}\right] / \mathrm{dt}=k_{2}\left[\mathrm{H}_{2} \mathrm{~S}\right]\left[\mathrm{O}_{2}\right]$

where $k_{2}$ is the second order rate constant $\left(\mathrm{M}^{-1} \mathrm{~h}^{-1}\right)$ and has the following form for $\mathrm{pH}=4-8$.

$\log k_{2}=10.5+0.16 \mathrm{pH}-\left(3 \times 10^{3}\right) \mathrm{T}^{-1}+0.49 \mathrm{I}^{1 / 2}$

From our concentration and rate data as in Figure 4 and using Eq. (9), we calculate using initial rate theory a $k_{2}$ of $6.99 \mathrm{M}^{-1} \mathrm{~h}^{-1}$ or $\log k_{2}$ of 0.845 assuming first order behavior for $\mathrm{HS}^{-}$and $\mathrm{O}_{2}$. Our 


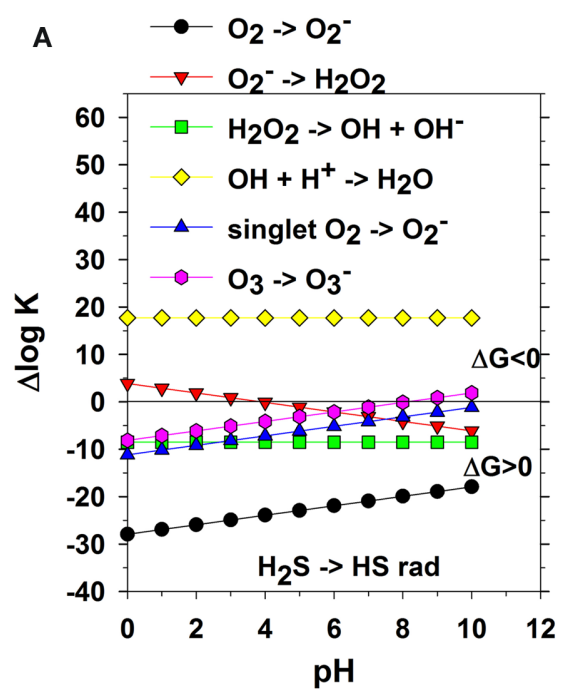

B
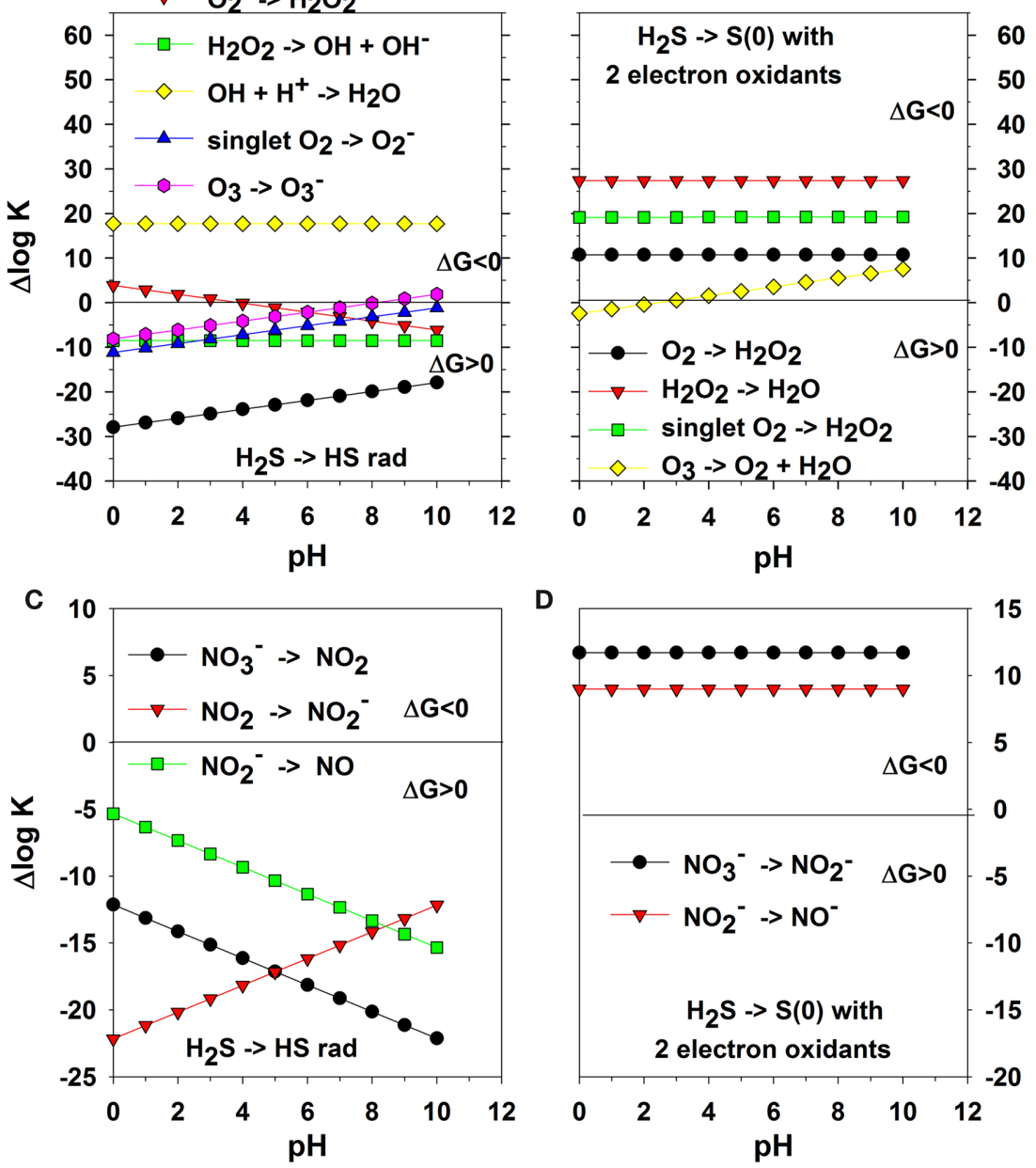

D

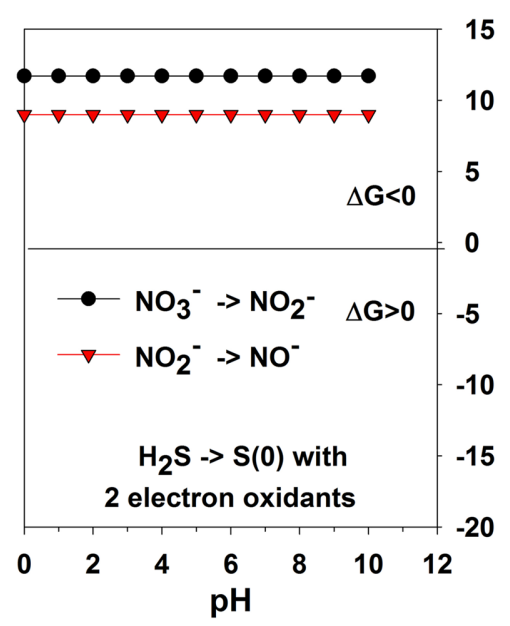

FIGURE 1 | One-electron transfer reactions of $\mathrm{H}_{2} \mathrm{~S}$ with oxygen species; the $+\Delta \log K$ on the $y$-axis indicates a favorable complete reaction and $-\Delta \log \mathrm{K}$ indicates an unfavorable reaction as $\Delta \mathbf{G}^{\circ}=-\mathbf{R T} \operatorname{lnK}=-\mathbf{2 . 3 0 3}$ $\mathbf{R T} \log \mathbf{K}$. HS ${ }^{-}$reactions are not included but are similar in reactivity (note pK of $\mathrm{H}_{2} \mathrm{~S} \sim 7$ and depends on salinity and temperature). (A) one-electron

transfer reactions of oxygen species coupled with Eq. 5. (B) two-electron transfer reactions of oxygen species coupled with Eq. 8. (C) one-electron transfer reactions of oxidized nitrogen species coupled with Eq. 5.

(D) two-electron transfer reactions of oxidized nitrogen species coupled with Eq. 8.

$k_{2}$ value is significantly smaller than that found by Millero et al. (1987). Because Millero et al. (1987) found a faster half-life of about 1-2 days for reactions at $\mathrm{pH}$ values similar to ours, we conclude that trace metal clean conditions hinder the oxidation of sulfide with $\mathrm{O}_{2}$. In their work, their plexi glass reaction vessel was rinsed with acid prior to (re)use whereas each experiment here was performed in a separate trace metal clean plastic tube. The trace metal clean condition shows clearly that the reaction of $\mathrm{O}_{2}$ and sulfide is not a favorable reaction.

In subsequent work, Vazquez et al. (1989) showed that the addition of trace metals in particular $\mathrm{Fe}$ (II) to the reaction vessel increased the rate of oxidation such that the half-life is on the order of minutes. Vazquez et al. (1989) showed that the rate doubled at the concentrations of Mn(II)found in the Black Sea, but increased 20-fold at the Fe(II) concentrations found at the Black Sea interface. The metal data indicate that the reaction of sulfide with oxygen is truly slow. As indicated by the thermodynamics, one-electron reactions are unfavorable whereas two-electron reactions are favorable, but have a kinetic problem due to the spin pairing problem with $\mathrm{O}_{2}$ (Figure 2). Ma et al. (2006) showed that a catalytic Fe, $\mathrm{O}_{2}, \mathrm{H}_{2} \mathrm{~S}$ cycle occurs at the oxic - anoxic interface, and this cycle results in sulfide oxidation to elemental sulfur.

\section{SULFIDE OXIDATION KINETICS OF ANAEROBIC PHOTOLITHOTROPHIC BACTERIA}

Figure 5 shows representative data for sulfide oxidation in the presence and absence of C. tepidum under laboratory light of $5 \mu \mathrm{mol}$ photons $\mathrm{m}^{-2} \mathrm{~s}^{-1}$. The rate of sulfide oxidation in the absence of cells is negligible as $\mathrm{O}_{2}$ or other dissolved oxidants are not present; thus, Eq. 9 is not operative. Any minor sulfide loss is due to volatilization. The loss of sulfide over time with C. tepidum $\left(3.3 \times 10^{9}\right.$ cells $\left.\mathrm{mL}^{-1}\right)$ 


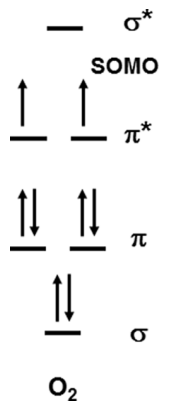

FIGURE 2 |The molecular orbital diagram for $\mathrm{O}_{2}$ showing the partially filled orbitals that accept electrons.

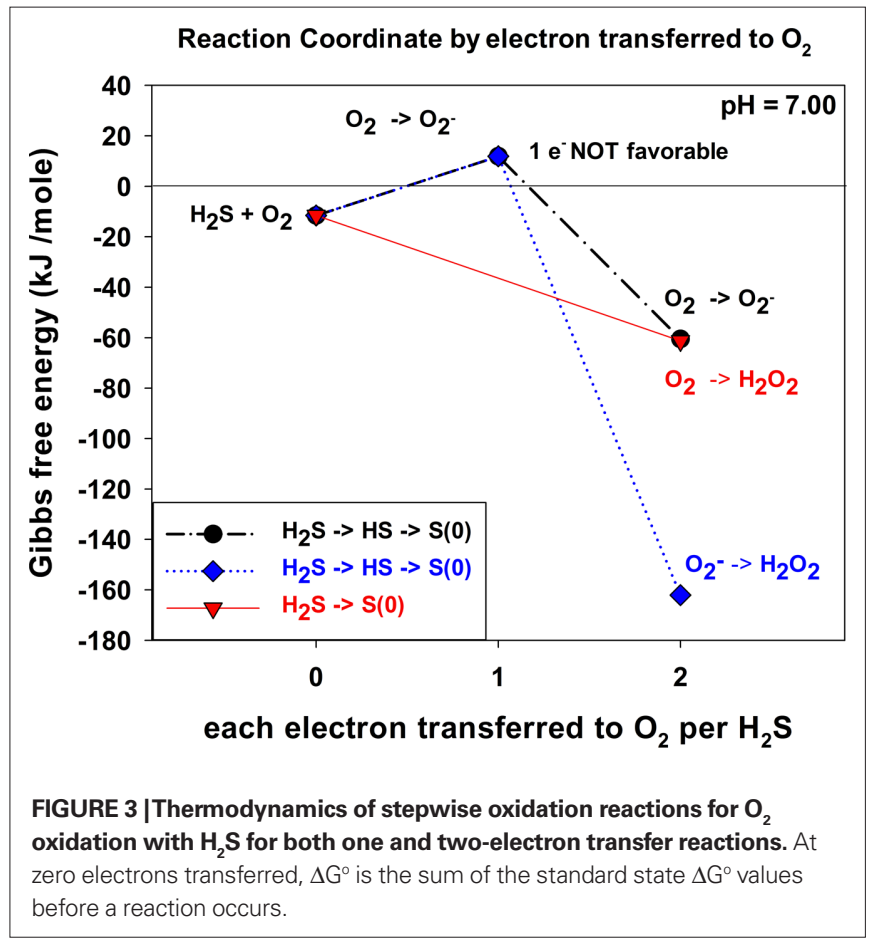

and light is linear with $r^{2}=0.949$ versus a first order plot for the $\ln$ (sulfide) versus time giving $r^{2}=0.930$. The linear plot of sulfide with time indicates that the reaction is zeroth order in sulfide and that sulfide oxidation depends on light as the external stimulus and not the concentration of sulfide as a reactant. The rate law for a zeroth order reaction is given as

$-d\left[\mathrm{H}_{2} \mathrm{~S}\right] / \mathrm{dt}=k$

which on integration gives

$k \mathrm{t}=\left[\mathrm{H}_{2} \mathrm{~S}\right]_{\mathrm{i}}-\left[\mathrm{H}_{2} \mathrm{~S}\right]$

where $\left[\mathrm{H}_{2} \mathrm{~S}\right]_{\mathrm{i}}$ is the initial sulfide concentration. In our experiments, the value of $k$ may include constants for the intensity of light and the number of cells.

This zeroth order kinetic pattern has been shown for Fe(II) oxidation in hot springs when cyanobacteria produce $\mathrm{O}_{2}$, which then reacts with $\mathrm{Fe}(\mathrm{II})$ and removes it as $\mathrm{Fe}$ (III) solid phases (Trouwborst

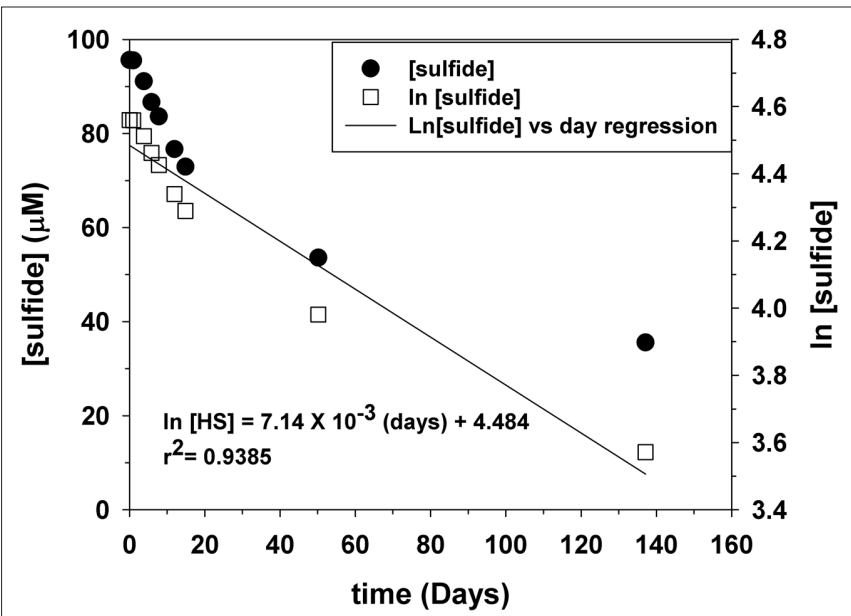

FIGURE 4 | Representative plot for the kinetics of sulfide oxidation in air saturated water under trace metal clean conditions. The In of the sulfide concentration versus time shows pseudo first order behavior.

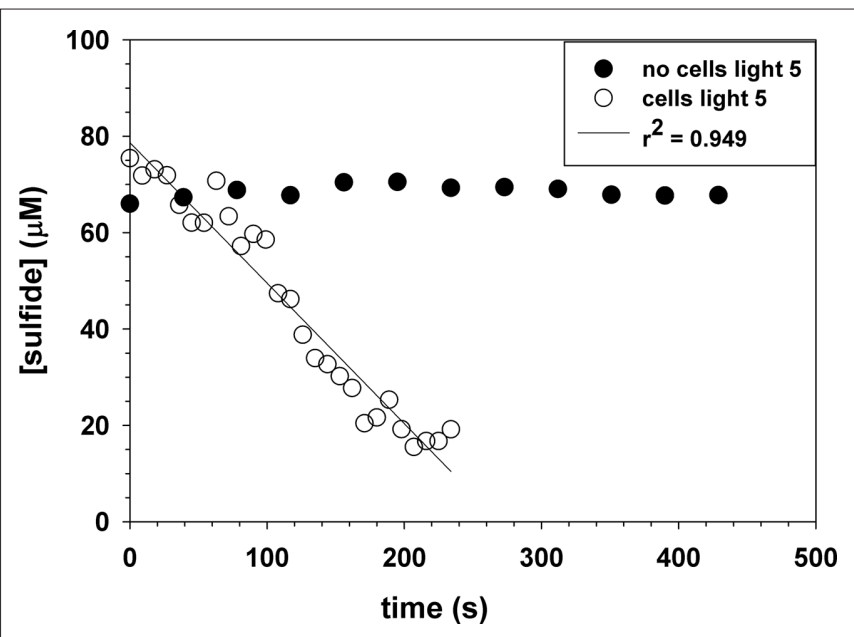

FIGURE 5 | Representative plot for the photo oxidation of sulfide in the presence of $\boldsymbol{C}$. tepidum cells during stationary growth phase with $\mathbf{5} \boldsymbol{\mu m o l}$ photons $\mathbf{~ m}^{-2} \mathbf{s}^{-1}$ of light intensity. The control with no cells shows no sulfide loss.

et al., 2007). The Fe(II) oxidation is external to the cyanobacterial cells whereas sulfide oxidation with $C$. tepidum occurs internally. Genetic experiments have shown that SQR is required for C. tepidum to grow with sulfide as the electron donor (Chan et al., 2009).SQR's are flavin containing enzymes that pass two-electrons from sulfide via the flavin cofactor to the quinone pool. The quinone pool ultimately is reoxidized by the activity of the photosynthetic reaction center. This model predicts the observed light dependence of sulfide oxidation as observed by the electrochemical experiments here.

In the presence of cells in stationary growth phase, the sulfide oxidation rate is $26,200 \pm 1200 \mu \mathrm{M} \mathrm{day}^{-1}$ at $44^{\circ} \mathrm{C}$ and a $\mathrm{pH}=7.4$. The data in Figures 4 and 5 can be compared to give relative rates for abiotic oxidation under trace metal clean conditions to biotic oxidation with C. tepidum cells of 0.91: 26,200. If we assume that the abiotic rate 
doubles for every $10^{\circ} \mathrm{C}$ increase, then the ratio becomes 1: 7,200 at $25^{\circ} \mathrm{C}$. Figure 6 shows the variation of sulfide oxidation rate versus cell counts when independent cultures of $C$. tepidum were in exponential phase growth. The average sulfide oxidation rate is $6,500 \pm 2900 \mu \mathrm{M}$ day $^{-1}\left(10^{9} \text { cells }\right)^{-1}$ at $44^{\circ} \mathrm{C}$ and a $\mathrm{pH}=7.4$. The rate of sulfide loss varies only eightfold over the two orders of magnitude range in cell count. Replicates rates for the same cell count and culture have a SD of $300 \mu \mathrm{M}$ day $^{-1}$ normalized to cell count. These data suggest that under most conditions, phototrophic sulfide oxidizers are not limited by the abiotic oxidation rate of sulfide under anoxic conditions. Furthermore, these data allow one to conclude that in anoxic systems dominated by anoxygenic phototrophs, biological sulfide oxidation rates will exceed abiotic oxidation by several orders of magnitude as no oxygen is present to oxidize sulfide. While the cell concentrations used here may seem high, in the New Zealand mats where C. tepi$d u m$ was isolated and in other microbial mat systems, cell densities of $10^{8}-10^{9} \mathrm{~g}^{-1}$ of sediment are not uncommon (Wahlund et al., 1991).

\section{SULFIDE OXIDATION KINETICS OF AEROBIC CHEMOLITHOTROPHIC SYMBIONTS AND FREE-LIVING ASSEMBLAGES}

As chemolithotrophic symbionts cannot be cultured in the lab, we relied on shipboard high-pressure incubations with freshly collected samples to make inferences about the nature and capacity

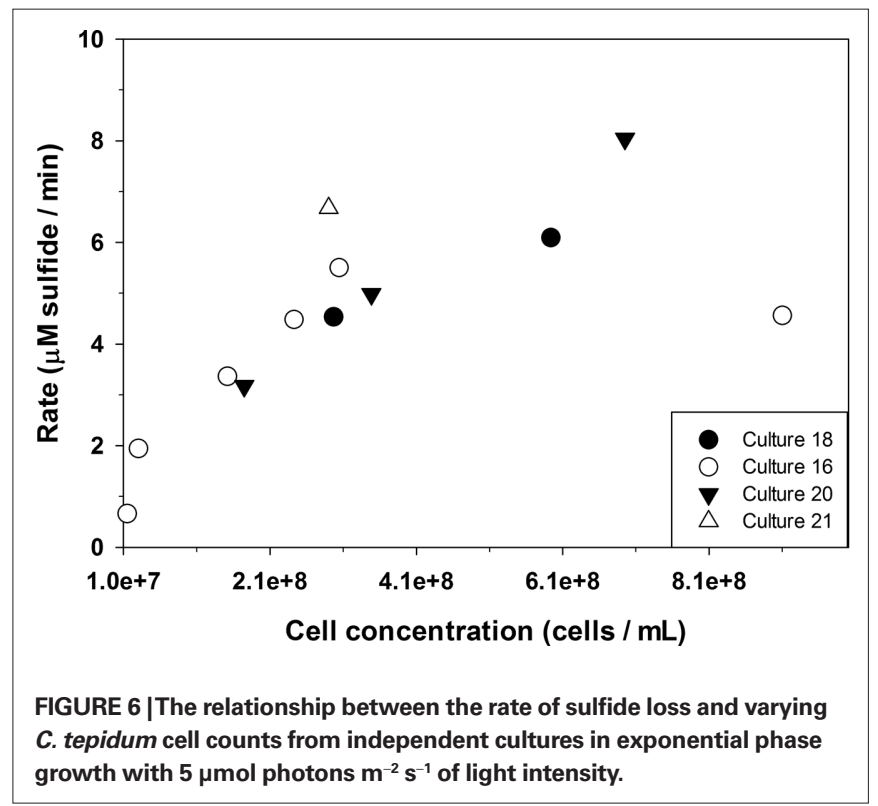

for sulfide oxidation. Table 1 shows data for the chemolithotrophic oxidation of sulfide by chemolithotrophic symbionts of the vent snail I. nautilei in high-pressure incubation chambers (geochemical conditions are described in the Materials and Methods). These incubations were conducted in the presence of sulfide $\left(\mathrm{H}_{2} \mathrm{~S}\right)$, and there is substantial uptake of $\mathrm{H}_{2} \mathrm{~S}$. Notably, the effluent from these vessels after exposure to I. nautilei showed substantial enrichment in polysulfide $S(-2)$ and $S(0)$ (Rozan et al., 2000) The sulfide oxidation rate from these data is $27.83 \pm 1.89 \mu \mathrm{M} \mathrm{min} \min ^{-1}(40,100 \mu \mathrm{M}$ day $^{-1}$ ) compared to the calculated abiotic rate of $0.0304 \mu \mathrm{M} \mathrm{min}{ }^{-1}$ $\left(43.8 \mu \mathrm{M} \mathrm{day}^{-1}\right)$ for these conditions using Eqs 9 and 10. Previous studies (Girguis and Childress, 2006) have also shown that the majority of sulfide oxidation is attributable to the symbiont. However, it is apparent that non-symbiotic animals, e.g., Urechis sp. worms, also have a native sulfide oxidation capacity though at substantially lower rates (Girguis et al., 2002). The data presented here are the first to characterize the different species of soluble oxidized sulfur compounds produced by intact symbioses, and future studies should aim to better characterize this response in other symbioses, as well as non-symbiotic animals.

Moreover, Table 2 also shows data for the chemolithotrophic oxidation of sulfide by free-living chemolithotrophic microbes in high-pressure incubation chambers (geochemical conditions are described in the Materials and Methods). The actual sulfide oxi-

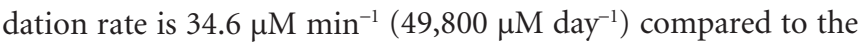
calculated abiotic rate of $0.0105 \mu \mathrm{M} \mathrm{m^{-1 }}\left(15.1 \mu \mathrm{M}\right.$ day $\left.{ }^{-1}\right)$ Eqs 9 and 10 .

These data clearly illustrate that biologically mediated oxidation of $\mathrm{H}_{2} \mathrm{~S}$ by $\mathrm{O}_{2}$ occurs rapidly, and indicates that chemolithotrophic microbes have found an efficient way to perform a two-electron transfer as in Figure 1B while overcoming any kinetic constraints based on the electron orbital diagram in Figure 2. These chemolithotrophic rates are over $10^{4}$ times that of the abiotic rate from Eqs 9 and 10 (Table 3). It is important to note that these data cannot resolve the relative contributions of sulfide oxidation by the mineralogical assemblage versus the biological community, but iron (oxy)hydroxide phases have rates on par with the trace metal catalyzed reactions (Vazquez et al., 1989). Again, these data provide a first glimpse at rates of sulfide oxidation by free-living microbes associated with sulfides, and future experiments should be aimed at differentiating the relative contributions of biotic and abiotic sulfide oxidation, as well as the relative differences in oxidation by different microbial communities (e.g., diffuse flow communities versus high temperature communities) and mineralogical assemblages.

Table 1 | Dissolved data for the chemolithotrophic oxidation of $\mathrm{H}_{2} \mathrm{~S}$ with $\mathrm{O}_{2}$ using $l$. nautilei in high-pressure incubation chambers.

\begin{tabular}{|c|c|c|c|c|}
\hline Organisms initial time (h) & Incurrent sulfide $(\mu \mathrm{M})$ & Excurrent $\mathrm{H}_{2} \mathrm{~S}(\mu \mathrm{M})$ & Excurrent $S(0)(\mu M)$ & $\begin{array}{l}\mathrm{H}_{2} \mathrm{~S} \text { uptake rate } \\
\left(\mu \mathrm{M} \text { min }^{-1}\right)\end{array}$ \\
\hline I. nautilei 12.43 & 312.5 & 20.69 & 25.04 & 26.3 \\
\hline I. nautilei 16.93 & 271.6 & 22.03 & 20.91 & 27.3 \\
\hline
\end{tabular}

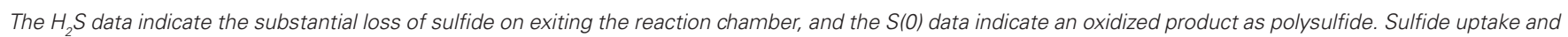
oxidation rate calculations are based on the mass of the animals in the chamber. 
Table 2 | Data for the chemolithotrophic oxidation of $\mathrm{H}_{2} \mathrm{~S}$ with $\mathrm{O}_{2}$ in high-pressure incubation chambers by free-living microbial communities (40 $\mathrm{mL}$ volume) recovered from hydrothermal diffuse flows.

\begin{tabular}{|c|c|c|c|}
\hline Organisms initial time (h) & Incurrent $\mathrm{H}_{2} \mathrm{~S}(\mu \mathrm{M})$ & Excurrent $\mathrm{H}_{2} \mathrm{~S}(\mu \mathrm{M})$ & $\begin{array}{l}\mathrm{H}_{2} \mathrm{~S} \text { uptake rate }\left(\mu \mathrm{M} \mathrm{min}^{-1}\right. \\
\mathrm{N}=\text { number of scans) }\end{array}$ \\
\hline Free-living community, 12 & 154.7 & 21.2 & 33.3 \\
\hline Free-living community, 22 & 137.2 & 16.9 & 30.3 \\
\hline Free-living community, 36 & 184.5 & 23.7 & 40.2 \\
\hline
\end{tabular}

The $\mathrm{H}_{2} \mathrm{~S}$ data indicate the substantial loss of sulfide on exiting the reaction chamber.

Table 3 | Comparative rates for the oxidation of sulfide under abiotic and biotic conditions.

Sulfide oxidation relative rate $\left(\mu \mathrm{M}\right.$ day $\left.^{-1}\right)$

\begin{tabular}{ll}
\hline SULFIDE OXIDATION WITH $\mathbf{O}_{\mathbf{2}}$ & \\
Trace metal clean (this work) & 1 \\
Millero et al. (1987) & 43.8 \\
Vazquez et al. (1989) - $8 \mu \mathrm{M}$ Mn(II) & 87.6 \\
Vazquez et al. (1989) - $0.3 \mu \mathrm{M}$ Fe(II) & 832 \\
I. nautilei with chemolithotrophic microbes & 40,100 \\
Chemolithotrophic microbes alone & 49,800 \\
SULFIDE OXIDATION WITHOUT $\mathbf{O}_{2}$ & \\
C. tepidum (stationary phase) & 7,200 \\
C. tepidum (exponential phase) & 1,625 \\
\hline
\end{tabular}

The first six entries oxygen is the oxidant. The last two entries are for the anaerobic photolithotroph. The relative rates are corrected to a temperature of $25^{\circ} \mathrm{C}$ as the $\mathrm{C}$. tepidum experiments were performed at $44-45^{\circ} \mathrm{C}$.

\section{CONCLUSION}

The goal for this work was to integrate theoretical chemical considerations with newly collected data to provide a concise rationale for why biological sulfide oxidation rates far exceed abiotic sulfide oxidation rates under both aerobic and anaerobic conditions. Direct comparison of the rates from our experiments with those from

\section{REFERENCES}

Arndt, C., Gaill, F., and H. Felbeck. (2001). Anaerobic sulfur metabolism in thiotrophic symbioses. J. Exp. Biol. 204, 741-750.

Baumgartner, L. K., Reid, R. P., Dupraz, C., Decho, A. W., Buckley, D. H., Spear, J. R., Przekop, K. M., and Visscher, P. T. (2006). Sulfate reducing bacteria in microbial mats: changing paradigms, new discoveries. Sediment. Geol. 185, 131-145.

Bernhard, J. M., Buck, K. R., Farmer, M. A., and Bowser, S. S. (2000). The Santa Barbara Basin is a symbiosis oasis. Nature 403, 77-80.

Bouchet, P., and Warén, A. (1991). Ifremeria nautilei, a new gastropod from hydrothermal vents, probably associated with symbiotic bacteria. Comptes Rendus De L'Academie Des Sciences Series III-Sciences De La Vie 312, 495-501.

Brendel, P., and Luther, G. W. (1995). Development of a gold amalgam voltammetric microelectrode for the determination of dissolved Fe, Mn, $\mathrm{O} 2$ and $\mathrm{S}(-2)$ in porewaters of marine and freshwater sediments. Environ. Sci. Technol. 29, 751-761.

Bruchert, V., Jorgensen, B. B., Neumann, K., Riechmann, D., Schlosser, M., and Schulz, H. (2003). Regulation of bacterial sulfate reduction and hydrogen sulfide fluxes in the central Namibian coastal upwelling zone. Geochim. Cosmochim. Acta 67, 4505-4518.

previous work (Table 3 ) indicate that chemolithotrophic sulfide oxidizers using $\mathrm{O}_{2}$ as the oxidant display sulfide oxidation rates over three orders of magnitude greater than the newly established abiotic oxidation rate of bisulfide. This new rate was determined in strict trace metal clean conditions and suggests that prior estimates of the direct reactivity of $\mathrm{HS}^{-}$with $\mathrm{O}_{2}$ are too high, and that biologically mediated sulfide oxidation may be responsible for the majority of oxidation observed in the field. The data from photolithotrophic organisms further indicates that biological processes in anaerobic environments are also likely to exceed abiotic rates of sulfide oxidation in aerobic environments, even when the presence of metal oxidants is considered. The implication of these findings is that flux of sulfide from anaerobic environments will largely be determined by the population size and activity of microbial communities in anaerobic-aerobic transition zones rather than by chemical oxidants alone. This implication is consistent with many other observations and is explained by the thermodynamic and kinetic constraints of 1 versus 2 -electron transfer reactions from $\mathrm{HS}^{-}$to $\mathrm{O}_{2}$.

\section{ACKNOWLEDGMENTS}

This work was supported by grants from the National Science Foundation to Thomas E. Hanson and George W. Luther III (MCB-0919682; OCE-0732439) and to Peter R. Girguis (OCE0732369) and a grant from NASA to Peter R. Girguis (NASAASTEP NNX07AV51G). We thank the crews of the ROV JASON II and the R/V Thomas G. Thompson for their expertise and help.

Canfield, D. E., and Raiswell, R. (1999). The evolution of the sulfur cycle. Am. J. Sci. 299, 697-723.

Canfield, D. E., Stewart, F. J., Thamdrup, B., De Brabandere, L., Dalsgaard, T., Delong, E. F., Revsbech, N. P., and Ulloa, O. (2010). A cryptic sulfur cycle in oxygen-minimum-zone waters off the Chilean coast. Science 330, 1375-1378.

Chan, L. K., Morgan-Kiss, R. M., and Hanson, T. E. (2009). Functional analysis of three sulfide:quinone oxidoreductase homologs in Chlorobaculum tepidum. J. Bacteriol. 191, 1026-1034.

Childress, J. J., Fisher, C. R., Favuzzi, J. A., Kochevar, R., and Sanders, N. K., Alayse, A. M. (1991). Sulfide-driven autotrophic balance in the bacterial symbiont-containing hydrothermal vent tubeworm, Riftia pachyptila Jones. Biol. Bull. 180, 135-153.

Clement, B. G., Luther, G. W. III, and Tebo, B. M. (2009). Rapid, oxygendependent microbial Mn(II) oxidation kinetics at sub-micromolar oxygen concentrations in the Black sea suboxic zone. Geochim. Cosmochim. Acta 73, 1878-1889.

Cline, J. D. (1969). Spectrophotometric determination of hydrogen sulfide in natural waters. Limnol. Oceanogr. 14, 454-458.

Cottrell, M. T., and Kirchman, D. L. (2003). Contribution of major bacterial groups to bacterial biomass production (thymidine and leucine 
incorporation) in the Delaware estuary. Limnol. Oceanogr. 48, 168-178.

Eghbal, M. A., Pennefather, P. S., and O'Brien, P. J. (2004). H2S cytotoxicity mechanism involves reactive oxygen species formation and mitochondrial depolarisation. Toxicology 203, 69-76.

Ellis, A. J., and Golding, R. M. (1959). Spectrophotometric determination of the acid dissociation constants of hydrogen sulphide. J. Chem. Soc. 127-130. doi:10.1039/JR9590000127

Girguis, P. R., and Childress, J. J. (2006). Metabolite uptake, stoichiometry and chemoautotrophic function of the hydrothermal vent tubeworm Riftia pachyptila: responses to environmental variations in substrate concentrations and temperature. J. Exp. Biol. 209, 3516-3528.

Girguis, P. R., Childress, J. J., Freytag, J. A., Klose, K. A., and Stuber, R. (2002). Effects of metabolite uptake on protonequivalent elimination by two species of deep-sea vestimentiferan tubeworm, Riftia pachyptila and Lamellibrachia cf luymesi. J. Exp. Biol. 205, 3055-3066.

Girguis, P. R., Lee, R. W., Desauliners, N., Childress, J. J., Pospesel, M., Felbeck, H., and Zal, F. (2000). Fate of nitrate acquired by the tubeworm Riftia pachyptila. Appl. Environ. Microbiol. 66, 2783-2790.

Henry, M. S., Childress, J. J., and Figueroa, D. (2008). Metabolic rates and thermal tolerances of chemoautotrophic symbioses from Lau Basin hydrothermal vents and their implications for species distributions. Deep Sea Res. Part 1 Oceanogr. Res. Pap. 55, 679-695.

Jannasch, H.W., and Wirsen, C. O. (1979). Chemosynthetic primary production at east Pacific sea floor spreading centers. Bioscience 29, 592-598.

Jorgensen, B. B. (1994). Sulfate reduction and thiosulfate transformations in a cyanobacterial matduring a diel oxygen cycle. FEMS Microbiol. Ecol. 13, 303-312.

Jorgensen, B. B., and Gallardo, V. A. (1999). Thioploca spp: filamentous sulfur bacteria with nitrate vacuoles. FEMS Microbiol. Ecol. 28, 301-313.

Julian, D., April, K. L., Patel, S., Stein, J. R., and Wohlgemuth, S. E. (2005). Mitochondrial depolarization following hydrogen sulfide exposure in erythrocytes from a sulfide-tolerant marine invertebrate. J. Exp. Biol. 208, 4109-4122.

Konovalov, S. K., Luther, G. W., Friederich, G.E.,Nuzzio, D. B., Tebo, B. M., Murray, J.W., Oguz, T., Glazer, B. T., Trouwborst, R. E., Clement, B., Murray, K., and Romanov, A. (2003). Lateral injection of oxygen with the Bosporus plume: fin- gers of oxidizing potential in the Black Sea. Limnol. Oceanogr.48, 2369-2376.

Lavik, G., Stührmann, T., Brücher, V., Van der Plas, A., Mohrholz, V., Lam, P., Mußmann, M., Fuchs, B.M.,Amann, R., Lass, U., and Kuypers, M. M. M. (2009). Detoxification of suphidic African shelf waters by blooming chemolithotrophs. Nature 457, 581-584.

Lin, X. J., Scranton, M. I., Chistoserdov, A. Y., Varela, R., and Taylor, G. T. (2008). Spatiotemporal dynamics of bacterial populations in the anoxic Cariaco Basin. Limnol. Oceanogr. 53, 37-51.

Luther, G. W. III. (2010). The role of one and two electron transfer reactions in forming thermodynamically unstable intermediates as barriers in multi-electron redox reactions. Aquat. Geochem. 16, 395-420.

Luther, G. W. III, Bono, A., Taillefert, M., and Cary, S. C. (2002). "A continuous flow electrochemical cell for analysis of chemical species and ions at high pressure: laboratory, shipboard and hydrothermal vent results," Chapter 4, in Environmental Electrochemistry: Analyses of Trace Element Biogeochemistry, Vol. 811, eds M. Taillefert and T. Rozan (Washington, DC: American Chemical Society Symposium Series), 54-73.

Luther, G. W. III, Glazer, B. T., Ma, S., Trouwborst, R. E., Moore, T. S., Metzger, E., Kraiya, C., Waite, T. J., Druschel, G., Sundby, B., Taillefert, M., Nuzzio, D. B., Shank, T. M., Lewis, B. L., and Brendel, P. J. (2008). Use of voltammetric solid-state (micro)electrodes for studying biogeochemical processes: laboratory measurements to real time measurements with an in situ electrochemical analyzer (ISEA). Mar. Chem. 108, 221-235.

Ma, S., Noble, A., Butcher, D., Trouwborst, R. E., and Luther, G. W. III. (2006). Removal of $\mathrm{H} 2 \mathrm{~S}$ via an iron catalytic cycle and iron sulfide precipitation in the water column of dead end tributaries. Estuar. Coast. ShelfSci. 70, 461-472. Maloy, J. T. (1985). "Nitrogen chemistry," in Standard Potentials in Aqueous Solution, 1st Edn, eds A. J. Bard, R. Parsons, and J. Jordan (New York: M. Dekker), 127-139.

Mentel, M., and Martin, W. (2008). Energy metabolism among eukaryotic anaerobes in light of Proterozoic ocean chemistry. Philos. Trans. R. Soc. Lond. B Biol. Sci. 363, 2717-2729.

Mickel, T. J., and Childress, J. J. (1982). Effects of pressure and temperature on the EKG and heart rate of the hydrothermal vent crab Bythograea thermydron (Brachyura). Biol. Bull. $162,70-82$.
Millero, F. J., Hubinger, S., Fernandez, M., and Garnett, S. (1987). Oxidation of $\mathrm{H} 2 \mathrm{~S}$ in seawater as a function of temperature, $\mathrm{ph}$, and ionic strength. Environ. Sci. Technol. 21, 439-443.

Overmann, J., and van Gemerden, H. (2000). Microbial interactions involving sulfur bacteria: implications for the ecology and evolution of bacterial communities. FEMS Microbiol. Rev. 24, 591-599.

Poulton, S. W., Krom, M. D., and Raiswell, R. (2004).A revised scheme for the reactivity of iron(oxyhydr)oxide minerals towards dissolved sulfide. Geochim. Cosmochim. Acta 68, 3703-3715.

Reinartz, M., Tschape, J., Bruser, T., Truper, H. G., and Dahl, C. (1998). Sulfide oxidation in the phototrophic sulfur bacterium Chromatium vinosum. Arch. Microbiol. 17, 59-68.

Rozan, T. F., Theberge, S. M., and Luther, G. W. III. (2000). Quantifying elemental sulfur (SO) bisulfide (HS-) and polysulfides ( $\mathrm{Sx2}$-) using a voltammetric method. Anal.Chim. Acta 415, 175-184.

Stanbury, D. (1989). "Reduction potentials involving inorganic free radicals in aqueous solution," in Advances in Inorganic Chemistry, Vol. 33, ed. A. G Sykes (New York: Academic Press), 69-138.

Stumm, W., and Morgan, J. J. (1996). Aquatic Chemistry, 3rd Edn. New York: John Wiley.

Theissen, U., Hoffmeister, M., Grieshaber, M., and Martin, W. (2003). Single eubacterial origin of eukaryotic sulfide : quinone oxidoreductase, a mitochondrial enzyme conserved from the early evolution of eukaryotes during anoxic and sulfidic times. Mol. Biol. Evol. 20, 1564-1574.

Trouwborst, R. E., Clement, B. G., Tebo, B. M., Glazer, B. T., and Luther, G. W. III. (2006). Soluble Mn(III) in suboxic zones. Science 313, 1955-1957.

Trouwborst, R. E., Johnston, A., Koch, G., Luther, G. W. III, and Pierson, B. K. (2007). Biogeochemistry of $\mathrm{Fe}(\mathrm{II})$ oxidation in a photosynthetic microbial mat: implications for precambrian $\mathrm{Fe}(\mathrm{II})$ oxidation. Geochim. Cosmochim. Acta 71, 4629-4643.

Turchyn, A. V., and Schrag, D. P. (2006). Cenozoic evolution of the sulfur cycle: insight from oxygen isotopes in marine sulfate. Earth Planet. Sci. Lett. 241, 763-779.

Vazquez, F. G, Zhang, J., and Millero, F. J. (1989). Effect of metals on the rate of the oxidation of $\mathrm{H} 2 \mathrm{~S}$ in seawater. Geophys. Res. Lett. 16, 1363-1366.

Wahlund, T.M., Woese, C. R., Castenholz, R., and Madigan, M. T. (1991). A thermophilic green sulfur bacterium from
New Zealand hot springs, Chlorobium tepidum sp. nov. Arch. Microbiol. 156, 81-90.

Wakeham, S. G., Amann, R., Freeman, K. H., Hopmans, E. C., Jorgensen, B. B., Putnam, I. F., Schouten, S., Damste, J. S. S., Talbot, H. M., and Woebken, D. (2007). Microbial ecology of the stratified water column of the Black Sea as revealed by a comprehensive biomarker study. Org. Geochem. 38, 2070-2097.

Wilmot, D. B., and Vetter, R. D. (1990). The bacterial symbiont from the hydrothermal vent tubeworm Riftia pachyptila is a sulfide specialist. Mar. Biol. 106, 273-283.

Windoffer, R., and Giere, O. (1997). Symbiosis of the hydrothermal vent gastropod Ifremeria nautilei (Provannidae) with endobacteria structural analyses and ecological considerations. Biol. Bull. 193, 381-392.

Yakushev, E., Pakhomova, S., Sørenson, K., and Skei, J. (2009). Importance of the different manganese species in the formation of water column redox zones: observations and modeling. Mar. Chem. 117, 59-70.

Yücel, M., Luther, G. W., and Moore, W.S. (2010). Earthquake-induced turbidite deposition as a previously unrecognized sink for hydrogen sulfide in the Black Sea sediments. Mar. Chem. 121, 176-186.

Conflict of Interest Statement: The authors declare that the research was conducted in the absence of any commercial or financial relationships that could be construed as a potential conflict of interest.

Received: 16 January 2011; accepted: 22 March 2011; published online: 09 April 2011.

Citation: Luther GW III, Findlay AJ, MacDonald DJ, Owings SM, Hanson TE, Beinart RA and Girguis PR (2011) Thermodynamics and kinetics of sulfide oxidation by oxygen: a look at inorganically controlled reactions and biologically mediated processes in the environment. Front. Microbio. 2:62. doi: 10.3389/ fmicb.2011.00062

This article was submitted to Frontiers in Microbial Physiology and Metabolism, a specialty of Frontiers in Microbiology. Copyright (c) 2011 Luther III, Findlay, MacDonald, Owings, Hanson, Beinart and Girguis. This is an open-access article subject to a non-exclusive license between the authors and Frontiers Media SA, which permits use, distribution and reproduction in other forums, provided the original authors and source are credited and other Frontiers conditions are complied with. 